\title{
$\AA$ lede er å lære bort
}

\section{Olav Røises store mål er å få dele sin kunnskap med medarbeidere og pasienter.}

Han har vært potetlaster og trailersjåfør. Han svermet for filosofi, men ble traumekirurg. Så fikk han lederrollen han brant for, så måtte han gi den opp. Men den Røise jeg møter, er pedagog.

- Jeg elsker å undervise. Jeg synes det er veldig gøy å dele kunnskap og kunne overføre verdifull innsikt jeg selv har oppnådd til andre. Det har vært et veldig viktig perspektiv i rollen min som lege også. Det handler om å sikre at pasienten klarer å forstå og dermed kan gjøre det jeg formidler til sitt eget. Det så du kanskje på Sunnaas?

Vi har møtt hverandre en gang før. De siste årene har de månedlige ortopediske kontrollene av multitraumepasienter på Sunnaas sykehus vært det eneste Olav Røise har igjen av sitt kjære klinikkarbeid. Den mørke mannen som snudde seg fra CTbildene og gransket meg og pasienten over brillene virket hard i starten, men myknet fort. Han spurte, lyttet, forklarte, viste og forklarte igjen. Det vi ikke fikk inn med teskje, fikk han inn med en mindre teskje. Tålmodig, folkelig, ivrig. Jeg visste ikke at traumekirurger var så joviale. Det hjelper antagelig å komme fra Toten.

\section{Selvvalgt er velvalgt}

- Bakgrunnen min har nok betydd veldig mye for meg. Jeg har jobbet som både trailer- og bussjåfør og sett verden fra et annet sted enn bare som akademiker og lege. Det har bidratt til å forme meg, spesielt med tanke på å ha respekt for andre. Jeg har også noen helt tydelige verdier hjemmefra som handler om ikke å akseptere løgn og urettferdighet, og å behandle folk ordentlig. Det er ting som sitter plantet i ryggmargen min, forteller Røise.

- Vil du si det var en streng oppvekst?

- Jeg hadde nok en selvoppofrende mor som var med på å mildne en streng far. Men jeg husker også at far hver jul dro en runde i bygda med et stort lass grønnsaker, som vi hadde god tilgang på, og ga bort til de andre. Så han var snill, men streng.

Snill og streng. Ikke helt ulikt mine egne tanker om sønnen hans etter vårt møte på
Sunnaas femti år senere. Men den strengheten jeg opplevde i starten var nok en velkalkulert del av Olav Røises pedagogiske metode.

- Jo mer kunnskap en pasient har, desto bedre er det for sluttresultatet. Det er tross alt pasientene som skal forstå valgene og leve med dem etterpå, selv om mange overlater selve beslutningen til legen, sier han - Så hvilken forskjell tror du denne forståelsen utgjør for pasientene?

- Jeg tror det er med på å ansvarliggjøre dem, slik at de blir i stand til å ivareta seg selv. Jeg er også sykehuspasient, og de val-

\section{«Jo mer kunnskap en pasient har, desto bedre er det for slutt- resultatet»}

gene som gjelder behandling, vil jeg gjerne ta selv. Men for å kunne ta dem må jeg også ha mer kunnskap om hva de innebærer.

\section{Finn fem feil}

Olav Røise ser klare paralleller til at det han som lege klarer å overføre til hver enkelt pasient, må også helsesystemet klare å overføre til befolkningen. Forebyggende helsearbeid er en hjertesak.

- Det forskningen sier noe om, er at det hjelper lite med bare informasjon. Du må gjøre egne erfaringer og oppleve den positive effekten av noe før du endrer atferd. Jeg har både Bekhterevs sykdom og masse slitasjegikt, og for min egen del har trening vært helt avgjørende. Det at jeg sykler mye, er det som faktisk gjør meg i stand til å kunne løpe en gang iblant. Med personlig erfaring gjennom mange år vet jeg at hvis jeg lar være å sykle, får jeg et dårligere funksjonsnivå. Forebyggende helsearbeid har et enormt potensial som vi i spesialisthelsetjenesten kan være med på å forløse dersom det blir lagt til rette for det. Det hjelper, men vi bruker ikke nok penger, tid og energi på det, slår han fast.

Selv om forebygging og helsepedagogikk er viktig for Røise, har han også andre kjepphester. En av favorittene i stallen er forbedringsarbeid. Finn fem feil, så finner du færre neste gang.

- Du har tidligere beskrevet feil som en «gullgruve for forbedring». Kan du si noe mer om hva du mener med det?

- Jeg har hele tiden lagt vekt på at det viktigste vi driver med, er å undersøke feilene våre og bruke dem til forbedringer. Jeg har til og med vært ute og kritisert mine egne for å være arrogante og ikke ydmyke nok til å ta selvkritikk. Drivkraften er at jo flere feil og uvaner vi kvitter oss med, desto bedre leger blir vi. Jeg har nok vært litt redd for «å kaste skitt på kolleger», men tror ikke jeg er blitt sett på som noen judas.

\section{«Hva? Men du er jo lege?!»}

På kontoret hans sitter jeg klemt inne mellom en bokreol med kilovis av den tyngste materien fra ortopediens og traumatologiens verdensrom og en overarbeidet stumtjener. Der henger en gul sykkeljakke med fartsflekker oppover ryggen. Jeg tenker det er en passende posisjon. En intim og røisisk atmosfære. Han sitter rett overfor meg, dratt ut fra pulten for å kunne snakke mot lydopptakeren som ligger på hyllen. Han har på seg mørke jeans og en hvit T-skjorte han sliter og drar en hel del i når han snakker. Nå om kultur.

- Åpenhet rundt feil har alt med kultur å gjøre. I dag er vi veldig forsiktige med å prøve å korrigere hverandre. Vi er utrolig redde for å tråkke på noen eller såre noen, og så har vi kanskje ikke helt klart for oss hva det vil si å være konstruktive. En del av problemet kan nok også være at de som studerer medisin er vant til alltid å være flinke, og at de blir engstelige for å vise andre at det er noe de ikke kan.

- Hva med deg selv? Kan du huske noen situasjoner der du selv har gjort feil eller vært usikker?

- Jeg har noen gufne erfaringer på det, ja, 


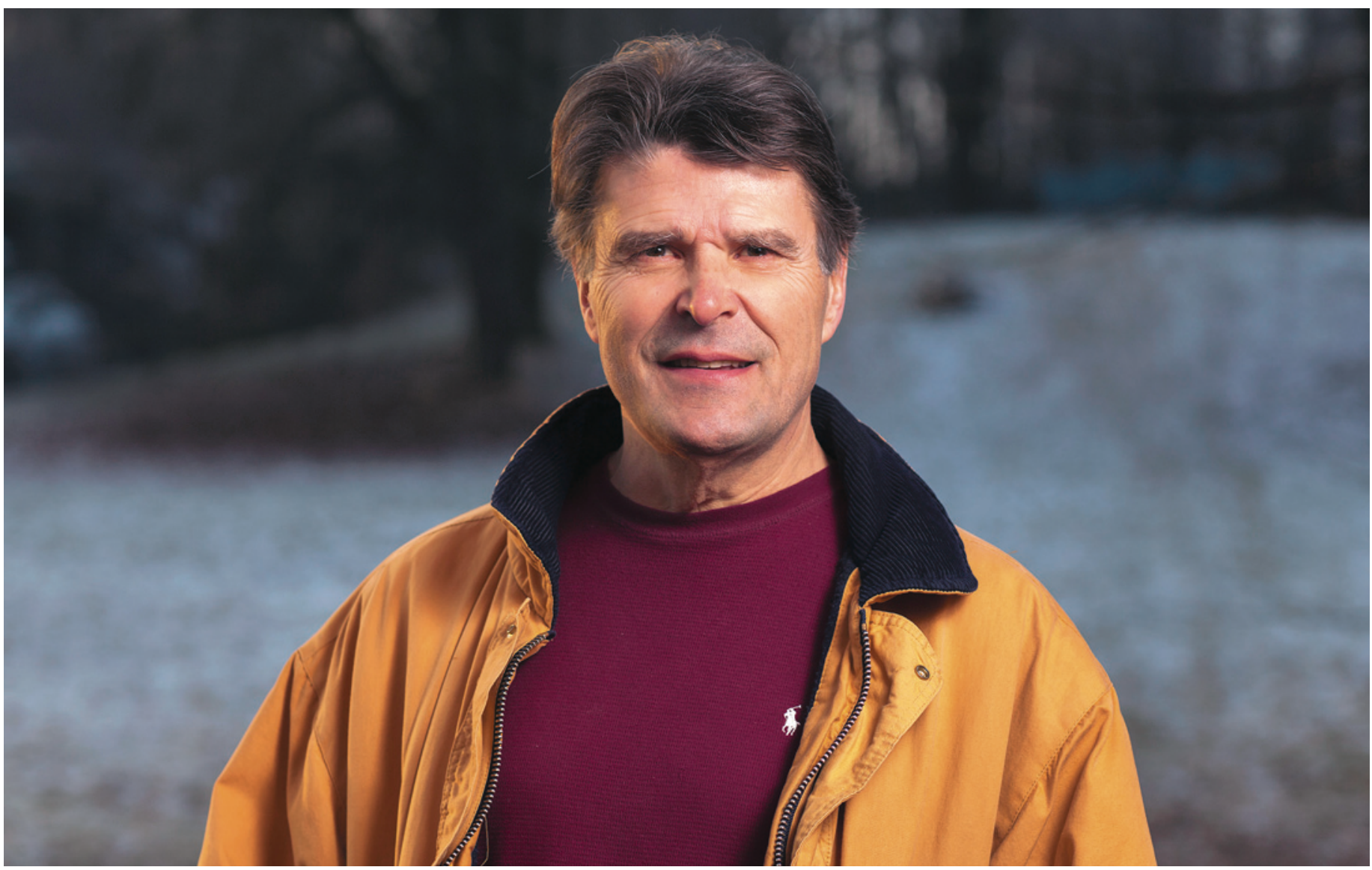

Foto: Niklas Lello

\section{Olav Røise}

\section{Født 20.1. 1952}

- Forskningsleder og professor

- Sosialdepartementets «Det nytter»prisen 1994 for forbedringsarbeid ved Ullevål sykehus

- Etablerte og bygde opp bekken- og hoftekirurgien ved Ullevål sykehus til nasjonal funksjon, 1993-2010

- Innførte operasjonsteknikk for å redde pasienter med livstruende blødninger i bekkenet i 1994

- Ledet innføringen av traumekurset ATLS til Norge i 1993 og ledet organisasjonen til 2012

- Ledet arbeidet med å innføre nasjonal traumeplan, 2006/2007

- Faglig leder av Nasjonalt traumeregister og leder av Interregional styringsgruppe for nasjonale kvalitetsregistre

- Mottok Legeforeningens lederpris 2016 sammen med Even Reinertsen men heldigvis har jeg aldri vært redd for å si «dette kan jeg ikke» Jeg var i distriktstjeneste i turnus i Finnmark der det var en fødestue med en jordmor som hadde jobbet der $i$ årevis. Jeg hadde vaktansvaret, men hadde vel bare vært med på tre fødsler eller noe sånt fra studiet. En gang ringte jordmoren meg fordi hun hadde problemer med en fødsel og trengte hjelp, og da måtte jeg jo innrømme at jeg ikke hadde så mye å tilby. Jeg stilte naturligvis opp og fikk lagt inn et drypp blant annet, men så måtte vi bare sende pasienten med ambulanse til sykehus. - Hvordan reagerte egentlig jordmoren da du sa at du ikke kunne hjelpe?

- Det var nok litt den holdningen: «Hva? Men du er jo lege?!» Det var nesten utenkelig for henne at en lege kunne si noe slikt i det hele tatt. Legen skulle vite alt. Hun kontaktet meg faktisk mange år senere etter at jeg hadde vært i mediene $\mathrm{i}$ forbindelse med noe annet. Da hadde hun nok reflektert litt over den episoden og kommet frem til at det som først kunne virke som en svakhet hos meg, egentlig var en styrke, forteller Røise.

\section{Fra avstand til avgrunn}

Det at Røise har følt seg trygg på å håndtere egen usikkerhet og ikke vært redd for å spørre, tror han har hjulpet ham til å unngå de farligste skjærene i den bølgende sjøen et sykehus er. Han har kolleger som har grunnstøtt og sunket. Men det er andre egenskaper hos ham som har ført til at det til tider har stormet friskt likevel.

- Du er opptatt av sykehusledelse og er kjent for å ha vært kritisk til hvordan lederrollene har utviklet seg de siste årene. Hva er problemet?

- De lederne jeg hadde i starten av min karriere, var veldig sterke og tydelige, mens jeg mener store deler av lederskapet i dag er blitt altfor utydelig. I disse svære enhetene vi har, virker den overordnede ledelsen veldig fjern, og de som står ytterst og har ansvaret for pasientbehandlingen, har fått en mye mer begrenset mulighet til å utøve ledelse. Fra toppen er det stort sett snakk om økonomi og besparelser. Mens de reelle besparelsene, som ikke går ut over pasientbehandlingen, er de man kan gjøre i ytterste ledd, nemlig ved å bruke ressursene riktig. - Men er det ikke sånn at alle leger fra alle spesialiseringer og $\mathrm{i}$ alle avdelinger mener de trenger mer penger?

- Det kan du nok si, men jeg mener også litt av problemet med denne avstanden er at de lederne som sitter ytterst, ikke opplever at de har noe egentlig ansvar for utgiftene. 
Det er veldig viktig at vi er nøkterne i vår ressursbruk. Vi skal gjøre det som er riktig, men ikke ta masse undersøkelser som ikke gir mening. Det er masse overbehandling som følge av at vi som legeledere ikke er tydelige nok på hva som er riktig medisin, understreker Røise.

Han har kjempet mange harde kamper for hvordan han selv mener helsekronene best kan komme pasientene til gode, men for ett års tid siden ble motstanden fra maskineriet for stor. Utviklingen han hadde advart mot, rullet stadig tyngre videre i dypere spor. Kursen var stødig, men retningen feil. Han måtte av.

\section{Uår}

- Jeg synes aldri det har vært så vanskelig å varsle om kritikkverdige forhold, fordi jeg har vært så trygg på at det jeg har stått frem med har vært riktig. Men den konflikten som førte til at jeg sluttet $i$ jobben min i fjor, den har rammet meg.

- På hvilken måte?

- Jeg valgte det jo selv, men det førte til at jeg nå har fått en helt annen rolle og ikke lenger har de samme mulighetene til å påvirke det som skjer. Og det er det jeg egentlig har lyst til. Men du ser jo hvor jeg sitter nå, ikke sant? På et lite kott, i utkanten av der beslutningene blir tatt.

Røise var leder for Klinikk for kirurgi og nevrofag ved Oslo universitetssykehus og hadde der jobbet med å utvikle en lærende organisasjonskultur. Han brant personlig for prosjektet og følte de var på riktig vei. Da det i november 2015 ble bestemt at klinikken han ledet skulle deles opp, frasa han seg stillingen sin og jobber nå som forskningsleder for Ortopedisk klinikk.

- Det var en opprivende sak, hvordan har det siste året vært for deg?

- Jeg har nok vært en del i dårlig humør, for å si det enkelt. Jeg har ikke gått inn i noen depresjon, men det har absolutt tatt på psykisk, det er det ikke tvil om, innrømmer han.

Heldigvis har Røise noen mindre stormfulle interesser enn å optimalisere norsk helsevesen. Han er lidenskapelig syklist og tråkker seg til jobb hver dag, sammen med kona. Men han ruller helst på landet.

- Når vi er på hytta på Syndin i Valdres, har jeg og familien flere ganger tatt den fantastiske turen fra Borlaug og ned til Lærdal langs gamleveien der. Den friske luften, all naturen du tar inn mens du sykler - det er helt fantastisk. Jeg trener aldri inne. Overhodet ikke.

\section{Valgets kvaler}

Olav Røise vokste opp med tre søsken i den lille bygda Kolbu på Toten i Oppland. Faren var grossist, drev med lastebiler og solgte grønnsaker, hovedsakelig poteter, fra bygd

\section{«Som filosofisk interes- sert var jeg i utgangs- punktet ghandist og tok avstand fra all vold»}

til by. Ortopeden startet leddslitasjen sin så tidlig som mulig og lempet potetsekker fra de var større enn han selv. På fritiden var langrennsinteressen enorm.

- Vi hadde en løype på 6-7 kilometer, og hver gang det hadde snødd, gikk vi opp løypa. Én i skisporet i midten, og to andre på siden som tråkket stavespor. - Stavespor? Sånn at man måtte treffe hullene hver eneste gang? Det hørtes merkelig ut...

- Nei, nei, tråkket stavespor. Det var jo ikke noen oppkjørte løyper, så vi måtte tråkke så hardt at stavene fikk tak når vi trente. Ellers ville de jo bare gå rett igjennom, forklarer han tålmodig.

Røise omtaler det nesten påfallende udramatisk, men han fikk hjernebetennelse $i$ tredje gym og var lenge mye plaget med hodepine. Etter hvert flyttet han til noen slektninger på Gjøvik for å være nærmere skolen. Etter gymnaset jobbet han som praktikant på sykehuset, men legevalget var ikke opplagt. - Jeg interesserte meg veldig for filosofi og kunne godt tenke meg å gå videre med det. Det var så fristende at da jeg kom inn på medisinstudiet, hadde jeg virkelig kvaler, men jeg valgte heldigvis medisin. - Heldigvis?

$-\mathrm{Ja}$, jeg opplever det som et fantastisk yrke og angrer ikke. Men jeg leste innmari mye bøker før i tiden, og det må jeg si jeg har savnet å få tid til ved siden av det store faglige engasjementet jeg har hatt.

\section{5 år med bakvakt}

Bygdegutten dro til byen for å studere, men ved siden av studiet og i ferier jobbet han helst som trailer- og bussjåfør. Ellers var det politikk på programmet.

- Som filosofisk interessert var jeg i utgangspunktet ghandist og tok avstand fra all vold. Men etter kuppet i Chile 11. september i 1973 lot jeg meg overbevise om at å følge en ikke-voldslinje ikke ville fungere. Jeg meldte meg inn i Norges kommunistiske studentforbund og var aktiv der lenge, forteller Røise.

- Bakgrunnen din som voldsmotstander kaster nytt lys over din Twitter-kritikk av proffboksing i Norge. Hva var det du reagerte på?

- Jeg må si jeg ble utrolig skuffet da jeg så statsministeren og kulturministeren hylle Cecilia Brækhus. For meg er det stor forskjell på å drive med idrett der du potensielt sett kan skade deg selv, sammenlignet med idrett der målet er å skade noen andre for å vinne. Jeg synes for å være helt ærlig at dette er noe som representerer det dyriske i mennesket, og det er ikke noe vi trenger å hylle.

- Skjønner. Et viktig spørsmål til slutt: Hva har vært det verste med å være lege?

- Det verste? Jeg har elsket jobben min og synes det var kjempespennende å bygge opp kompetanse på avansert bekkenkirurgi på Ullevål. I praksis var jeg bakvakt kontinuerlig i 15 år, men selve arbeidet var egentlig ikke noen stor belastning for meg. Belastningen var at det gikk på bekostning av noen, nemlig familien, vedgår Røise.

Han og kona har to barn, og selv om de skiller lag på Vinderen når de sykler til jobben, har de holdt sammen opp gjennom alle bakvaktene.

Forskningslederen kommer til å fortsette å spenne på seg sykkelskoene to ganger om dagen, men i konfliktenes korridorer på sykehuset har han satt igjen et par velbrukte arbeidssko. De blir ikke lette å fylle.

\section{Rune Skogheim}

runeskogheim@hotmail.com 